\title{
Cogenerations of energy from sugar factory bagasse
}

\author{
Assefa Alena, Omprakash Sahu* \\ Department of Chemical Engineering, Wollo University, Kombolcha, South Wollo Ethiopia
}

Email address:

ops0121@gmail.com (O.Sahu)

\section{To cite this article}

Assefa Alena, Omprakash Sahu. Cogenerations of Energy from Sugar Factory Bagasse, American Journal of Energy Engineering. Vol. 1, No. 2, 2013, pp.22-29. doi: 10.11648/j.ajee.20130102.11

\begin{abstract}
During sugar production, bagasse (waste) is produced which is used as energy resource in the sugar mill. Cogeneration power plants using bagasse as the feedstock are attached to several sugar factories in Thailand. These produce steam and electricity for use in the sugar mills and also sell the excess power to the grid. Bagasse, being a by-product of sugar production as well as of biomass origin seems to be a suitable candidate for sustainable energy production. However the case is quite different in Shoa Sugar Factory, which suffers from lack of bagasse during stoppage of mill and as a matter of fact it is forced to cut trees of the surrounding to deliver it to its boilers during stoppage of mill. It is a crystal clear fact that cutting trees without replacement causes the desertification, which is currently the case in Shoa Sugar Factory. It is from this fact that the objectives of the research work emanate. The first part of the study deals with bagasse and its properties, this part of the study focuses on determining the quality and quantity of bagasse that has been used by the factory as a fuel for boilers with respect to the conventionally accepted standards. The outcome of the study indicates the bagasse produced by the factory fulfills all the requirements as a boiler fuel both in quality and quantity wise, during milling time and stoppage of mill without the supply of any additional fuel. The second part of the study focuses on the steam generation and utilization unit. The study conducted in the steam generation unit shows the steam generation unit (boilers) has very low efficiency (on average 56\%) when compared to the minimum accepted efficiency of boiler that uses bagasse as a fuel $(70 \%)$. The low efficiency is manifested by large quantity of heat losses that should be transferred to steam. The investigation on the steam utilization unit shows it operates without problems. In general the outcome of the study proves that the low efficiency of the boiler resulted in shortage of surplus bagasse. The research output indicates existing surplus bagasse shortage can be solved by improving the efficiency of the steam generation unit. The proposed solutions to the problems are optimization of excess air supply in the combustion chambers, application of bagasse drying system, increasing the capacity of evaporators, efficient operations, maintenance of boilers and its accessories.
\end{abstract}

Keywords: Bagasse, Energy, Fuel, Heat

\section{Introduction}

The development of sugar industry in Ethiopia has been remarkable since 1954 when the Dutch Company, HVA established Wonji Sugar Factory with a crushing rate of 1400 tons of cane per day (TCD). Wonji Sugar Factory is the pioneer sugar factory in Ethiopia. Eight years after the establishment of Wonji Sugar Factory, in 1962 Shoa Sugar Factory was established with a crushing rate of 1600 TCD. However, the present crushing capacity of the factory is 1700 TCD. The two Factories are located in the rift valley, Orimia region, in East Central Ethiopia, some $107 \mathrm{Km}$ South East of Addis Ababa at an elevation of 1540 above sea level[1,2]. They are under one management and collectively called Wonji Shoa Sugar Factory (WSSF). Since then the sugar sector has played a vital role in the country's economy and sugar has become one of the major commodities for local consumption and foreign exchange earnings. The production of sugar from sugar cane is a distinctive process in that it involves no element of synthesis [3]. However, sucrose comes in to the factory and subject to some unit operations [4]. The present system of sugar manufacturing process is essentially a combination of juice extraction from sugar cane by milling or diffusion or a combination of both, clarification of juice, concentration of juice by evaporation to syrup, crystallization of sucrose by vacuum pan boiling, centrifugal separation of sugar and molasses from massacuites, drying and cooling of sugar and sugar grading and packing $[5,6]$. All the process needs relatively large amount of energy in different forms such as power for prime movers. This power is needed mainly in 
the form of electricity for the electric motors and medium to high-pressure steams for the steam engines and steam turbines [7]. The processing of raw cane also requires a large amount of heat provided by low-pressure steam for the processing of juice in to commercial sugar $[8,9]$. Sugar cane industry is one of the few industries, which are able to supply its own fuel (in the form of bagasse). The fiber in the cane is generally sufficient to supply all the steam necessary for power production and for manufacture of sugar when utilized as a fuel in the boiler furnaces. With normal fiber content in cane (12-14\%) a well balanced factory will be left with a surplus bagasse [10]. Nevertheless, the energy crises of 1974 and 1979 and the uncertainty in the future pricing of fossil fuel has led most sugar producers to think in terms of improved energy balance in their factories. Technological advance in the utilization of by- products of the cane sugar industry have reinforced the policy of maximum efficiency in the use of fuel [11].

The present objective of cane sugar industry is to extract the maximum power from the available fuel by efficiently utilizing the latent heat of steam and reducing the losses to a minimum. The losses are inevitably sustained in the flue gases of steam boiler, gas turbines and in the cooling water of condensers. Significant improvements can be achieved by improving boiling house, and other factory departments leading to maximum process heat economy, bagasse drying to improve its calorific value as fuel, generation of extra electricity from excess bagasse for export to the grid. Shoa sugar factory is the factory that was established to supply its own fuel from the byproduct bagasse and remains with some excess of this bagasse, which will be used during stoppage of mill so that no additional fuel would be used whatever the case may be. At the present condition the reality reveals that the factory is using additional fuel during mill stoppage.

\section{Material and Methods}

In this research work the detail assessments of the factory has been made by giving due attention on review of existing steam generation plant, present condition and performance of boiler capacity, drum boiler heating surfaces, fittings for boilers attemperator, soot blowers grate, economizer, induced draft( ID) fan, combustion air fan (FD fan), chimney, instrumentation and controls, steam distribution system, steam pressure reducers and de-superheating station, various indicators and recorders installed, lagging and insulation, evaporator station, thermo compressor, juice catcher after last body, condensate extraction system, material and energy balance based on design parameters. The flow diagram of power plant is shown in Fig. 1. The research work, therefore, emanates from current energy imbalance, shortage of excess bagasse, and wastage of steam. To arrive at the solution the number of works was conducted, among which are; Investigating the obscure operating characteristics, which are specific to steam generation from bagasse as a boiler fuel and utilization of steam by the factory, identifying the root causes of the problem, examining the extent to which the energy system analysis can be used to know the energy impact of the factory, quantifying and evaluating the performance parameters of the factory with respect to steam generation and utilization, studying the effects of the change in the performance parameters which accounts to prevent the existing problems, recommend appropriate solutions[12].

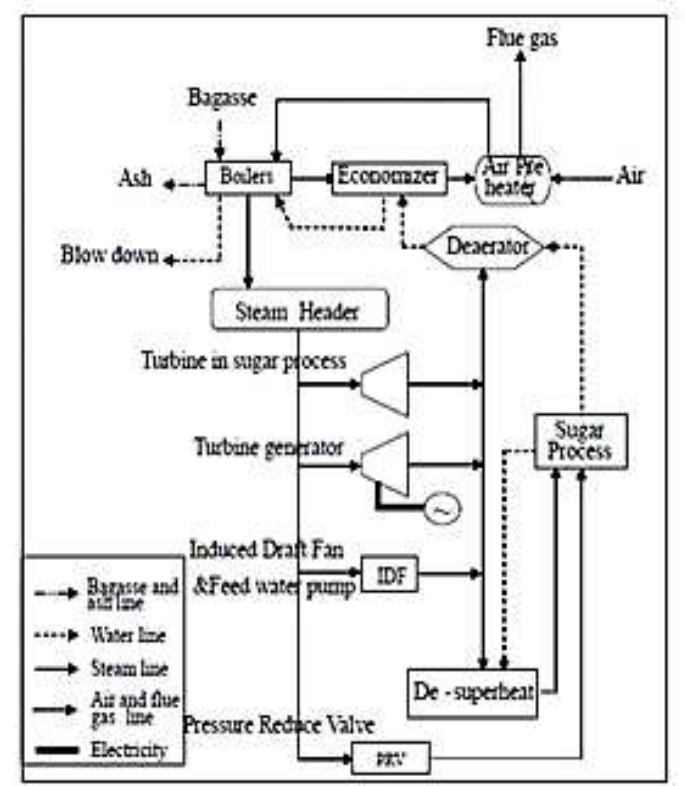

Fig. 1. Power plant of Sugar Industry.

\subsection{Physical Testing}

Materials used for experiment are, Chopping machine, disintegrator, balances, sodium bicarbonate, and mercuric chloride to determine fiber content of the cane. Perforated tray, balances and Oven were to determine the moisture content of bagasse. Rapi-pol extractor, lead acetate, filter paper and balances: it is used to determine the Pol in bagasse. Bomb Calorimeter, type C210, Make: Junk \& Kunkel K.G, IKA WERK Stauten Breisgan, measuring cylinder, balances and ignitions wire were used to determine the high heating Value (HHV) or gross calorific value of Bagasse of different Varieties and different moisture content. Combustion (Flue Gas) Analyzer, KM9104 was used to determine the composition of the flue gas leaving the boiler and its temperature [13].

\section{Results and Discussion}

\subsection{Physical Property of Bagasse}

The physical property of bagasse after testing is shown in Table no. 1. In which moisture content in bagasse, fiber content in cane, bagasse content in cane and percentage of pol in bagasse was determine. 
Table 1. Physical Properties of Bagasse.

\begin{tabular}{lllll}
\hline Variety & $\begin{array}{l}\text { Moisture } \\
\text { content } \\
\text { in } \\
\text { bagasse } \\
{[\mathbf{w t} / \mathbf{w t} \%]}\end{array}$ & $\begin{array}{l}\text { Fiber } \\
\text { content } \\
\text { in cane } \\
{[\mathbf{w t} / \mathbf{w t} \%}\end{array}$ & $\begin{array}{l}\text { Bagasse } \\
\text { content } \\
\text { in cane } \\
{[\mathbf{w t} / \mathbf{w t} \%]}\end{array}$ & $\begin{array}{l}\text { Pol } \\
\text { \%in } \\
\text { bagasse }\end{array}$ \\
\hline N-140 & 50 & 14.52 & 32 & 3.8 \\
NCO334 & 50 & 14.08 & 30 & 3.4 \\
B52-298 & 50 & 13.67 & 29 & 3.2 \\
B41-227 & 50 & 14.78 & 33 & 3.7 \\
CO-421 & 50 & 14.13 & 31 & 3.6 \\
Average & 50 & 14.24 & 31 & 3.54 \\
\hline
\end{tabular}

\subsection{Gross Calorific Value}

The heating value of bagasse from cane was shown in Table no.2. In this test determine percentage of moisture, percentage of fiber in cane and gross calorific value was determined from different varieties of cane.

Table 2. Heating Values of Bagasse Obtained from Major Commercial Cane Varieties.

\begin{tabular}{llll}
\hline Variety & Moisture \% & Fiber \% Cane & GCV[KJ/Kg] \\
\hline N-140 & 50 & 14.52 & 8795 \\
NCO334 & 50 & 14.08 & 8430 \\
B52-298 & 50 & 13.67 & 8396 \\
B41-227 & 50 & 14.78 & 8894 \\
CO-421 & 50 & 14.13 & 8469 \\
Average & 50 & 14.24 & 8597 \\
\hline
\end{tabular}

*GCV Gross Calorific Value.

\subsection{Calorific Value of Bagasse}

The calorific value of bagasse before and after drying was presented in Table no. 3. In this calculation both gross calorific value and net calorific value was determine.

Table 3. Calorific Values of Bagasse with Different Moisture Content.

\begin{tabular}{llll}
\hline Bagasse & Before drying & \multicolumn{2}{l}{ After drying } \\
\hline Moisture (\%) & 50 & 35 & 30 \\
$\mathrm{GCV}(\mathrm{KJ} / \mathrm{Kg})$ & 8597 & 12544 & 13602 \\
$\mathrm{NCV}(\mathrm{KJ} / \mathrm{Kg})$ & 7447 & 10517 & 11532 \\
\hline
\end{tabular}

*GCV Gross Calorific Value, NCV Net Calorific Value.

\subsection{Composition of Gasses}

The analysis of flue gasses was presented in Table no. 4. The percentage of different gaseous oxygen, carbon monoxide, carbon dioxide, nitrogen and water at boiler temperature was determined.

Table 4. Results of Flue Gasses Analysis.

\begin{tabular}{llll}
\hline \multirow{2}{*}{ Description } & \multicolumn{3}{l}{ \% of flue gases compositions } \\
\cline { 2 - 4 } & B\#1 & B\#2 & B\#3 \\
\hline Oxygen & 9.4 & 10.5 & 11.3 \\
$\mathrm{CO}$ & 0.89 & 1.23 & 1.84 \\
$\mathrm{CO}_{2}$ & 10.9 & 9.8 & 9.1 \\
$\mathrm{~N}_{2}$ & 65 & 76.97 & 63 \\
$\mathrm{H}_{2} \mathrm{O}$ & 13.8 & 12.4 & 14.3 \\
Temperature & 202 & 218 & 220 \\
\hline
\end{tabular}

\subsection{Bagasse and Steam Balance based on Actual Daily Production}

The balances conducted based on the bagasse and steam demand of the factory on daily basis of its present operation condition is intended as one of the factors to address the present fuel problems of the factory. The factory crushes on average 22 hours a day in which this balance is based on. In the determinations of the amount of bagasse and steam produced and consumed, the first step is the determination of loses $[14,15]$.

1) These loses includes bagasse loses due to vacuum filter, stoppage of mill and other undetermined loses.

2) Heat loses in the processes of steam generation comprises of loses due to Latent heat of vaporization of the water formed by combustion of the hydrogen contained in the bagasse. This is lost in the flue gases with the water vapor if the latent heat is not condensed.

3) Latent heat of vaporization of the water content of bagasse, which in the same way is lost with the flue gases, Losses in ash content and brix of bagasse.

4) Sensible heat losses in the flue gases and fly ash.

5) Losses by radiation

6) Losses by unburned solid,

7) Losses by incomplete combustion of carbon giving $\mathrm{CO}$ instead of $\mathrm{CO} 2$.

Except loses due to sensible heat in the flue gases and fly ash, radiation, unburned solid, and incomplete combustion of carbon giving $\mathrm{CO}$ instead of $\mathrm{CO} 2$, the rest loses are included in the determinations of the N.C.V of bagasse. The rest loses will therefore determined here under, which presented in Table no. 5. 
Table 5. Bagasse and steam balance based on actual daily production.

\begin{tabular}{|c|c|c|c|c|}
\hline 4. Descriptions & Unit & Quantity & & \\
\hline 1. Cursing Rate & $\begin{array}{l}\text { T/h } \\
T / d\end{array}$ & $\begin{array}{l}77 \\
1700\end{array}$ & & \\
\hline 2. Fiber in can & $\%$ & 14.24 & & \\
\hline 3. Average Bagasse in cane & $\%$ & 31 & & \\
\hline \multicolumn{5}{|l|}{ 4.1. Bagasse Analysis } \\
\hline $\begin{array}{l}\text { (i) Pol in bagasse } \\
\text { (ii) Moisture in bagasse } \\
\text { (iii) Fiber in bagasse }\end{array}$ & $\begin{array}{l}\% \\
\% \\
\%\end{array}$ & $\begin{array}{l}3.54 \\
50 \\
46.46\end{array}$ & & \\
\hline \multicolumn{5}{|l|}{ 4.2. Bagasse loses } \\
\hline $\begin{array}{l}\text { (i) For Vacuum. Filter and other losses in cane } \\
\text { (ii) For stoppages of cane shortage ( } 8 \% \text { on pro- } \\
\text { duction and } 85 \% \text { steam usage) }\end{array}$ & $\begin{array}{r}\% \\
-\quad \%\end{array}$ & $\begin{array}{l}2.38 \\
58.59\end{array}$ & & \\
\hline 4.3. Net Bagasse available $\%$ cane & $\mathrm{T} / \mathrm{n}$ & 18.48 & & \\
\hline \multicolumn{5}{|l|}{ 4.4. Calorific value of Bagasse } \\
\hline $\begin{array}{l}\text { (i) G.C.V } \\
\text { (ii)N.C.V }\end{array}$ & $\begin{array}{l}\mathrm{KJ} / \mathrm{kg} \\
\mathrm{KJ} / \mathrm{kg}\end{array}$ & $\begin{array}{l}8594 \\
7447\end{array}$ & & \\
\hline $\begin{array}{l}\text { 5.1. Steam Condition } \\
\text { Pressure } \\
\text { Temperature } \\
\text { Temp. of feed water tank } \\
\text { Temp. of feed water after economizer } \\
\text { The gas exit temp } \\
\text { Ambient Temp } \\
\mathrm{CO}_{2} \\
\text { Air fuel Ratio } \\
\text { Heat-losses in flue gases } \\
\text { Capacity } \\
\text { Steam/Bagasse Ratio }\end{array}$ & $\begin{array}{l}\text { Unit } \\
\mathrm{Kg} / \mathrm{cm}^{2}(\mathrm{~g}) \\
\text { OC } \\
\text { OC } \\
\text { OC } \\
\text { OC } \\
\text { OC } \\
\% \\
\\
\mathrm{~kJ} / \mathrm{kg} \\
\mathrm{T} / \mathrm{h}\end{array}$ & $\begin{array}{l}\text { Boiler } 1 \\
21 \\
310 \\
90 \\
187 \\
202 \\
30 \\
10.9 \\
1.79 \\
1399 \\
15.002 .03\end{array}$ & $\begin{array}{l}\text { Boiler } 2 \\
21 \\
330 \\
90 \\
187 \\
218 \\
30 \\
9.8 \\
1.89 \\
1605 \\
15.00 \\
1.99\end{array}$ & $\begin{array}{l}\text { Boiler } 3 \\
22 \\
320 \\
90 \\
190 \\
220 \\
30 \\
9.1 \\
1.98 \\
1685 \\
15.00 \\
1.98\end{array}$ \\
\hline \multicolumn{5}{|l|}{ Efficiency } \\
\hline Factor- Alpha (solid unburned) & $\%$ & 95 & 95 & 95 \\
\hline Factor -Beta (radiat $\mathrm{CO}_{2} \&$ Conv.) & $\%$ & 95 & 95 & 95 \\
\hline Factor - Neta (In.Comb.) & $\%$ & 95 & 95 & 95 \\
\hline Product : $A * B * N$ & $\%$ & 85.7 & 85.7 & 85.7 \\
\hline \multicolumn{5}{|l|}{ Boiler Efficiency } \\
\hline $\begin{array}{l}\text { (i)On G.C.V } \\
\text { (ii) On. N.C.V }\end{array}$ & $\begin{array}{l}\% \\
\%\end{array}$ & $\begin{array}{l}58 \\
69\end{array}$ & $\begin{array}{l}56 \\
67\end{array}$ & $\begin{array}{l}55.5 \\
66\end{array}$ \\
\hline \multicolumn{5}{|l|}{ Boiler Efficiency } \\
\hline $\begin{array}{l}\text { (i)On G.C.V } \\
\text { (ii) On. N.C.V }\end{array}$ & $\begin{array}{l}\% \\
\%\end{array}$ & $\begin{array}{l}58 \\
69\end{array}$ & $\begin{array}{l}56 \\
67\end{array}$ & $\begin{array}{l}55.5 \\
66\end{array}$ \\
\hline \multicolumn{5}{|l|}{ 5.2 Steam Generation Possible } \\
\hline $\begin{array}{l}\text { Capacity } \\
\text { Steam pressure } \\
\text { Steam temperature } \\
\text { Steam/Bagasse Ratio }\end{array}$ & $\begin{array}{l}\mathrm{T} / \mathrm{h} \\
\mathrm{Kg} / \mathrm{cm}^{2} \\
{ }^{\circ} \mathrm{C}\end{array}$ & $\begin{array}{l}15 \\
21 \\
310 \\
2.03\end{array}$ & $\begin{array}{l}15 \\
21 \\
330 \\
1.99\end{array}$ & $\begin{array}{l}15 \\
21 \\
3201.98\end{array}$ \\
\hline
\end{tabular}




\begin{tabular}{|c|c|c|c|c|}
\hline 6.1. Mill TurbinesCapacity & hp & 300 & 450 & 450 \\
\hline \multicolumn{5}{|l|}{ Live steam condition } \\
\hline Pressure & $\mathrm{Kg} / \mathrm{cm}^{2}$ & 21 & 21 & 21 \\
\hline Temperature & ${ }^{\circ} \mathrm{C}$ & 300 & 300 & 300 \\
\hline Exhaust steam pressure & $\mathrm{Kg} / \mathrm{cm}^{2} \mathrm{t} / \mathrm{n}$ & 1.25 & 1.25 & 1.25 \\
\hline Steam flow at operational load & \multicolumn{4}{|c|}{ Total12.32 } \\
\hline 6.2. Power turbine & \multirow{7}{*}{$\begin{array}{l}\mathrm{Kg} / \mathrm{cm}^{2} \\
0 \mathrm{C} \\
\mathrm{Kg} / \mathrm{cm}^{2} \\
\mathrm{MW} \\
\mathrm{Kg} / \mathrm{MWh} \mathrm{T} / \mathrm{n}\end{array}$} & Turbine 1 & \multicolumn{2}{|l|}{$\mathrm{T}$ turbine 2} \\
\hline Pressure & & 21 & 20 & \\
\hline Temperature & & 300 & 300 & \\
\hline Exhaust steam pressure & & 1.25 & 1.25 & \\
\hline Operation Av. Load & & 1.4 & 1.4 & \\
\hline Specific steam consumption & & 1.68 & 11.68 & \\
\hline Steam flow at operational load & & 18 & 18 & \\
\hline \multicolumn{5}{|l|}{ 6.3 Steam to process } \\
\hline Exhaust from Mill turbine & $\mathrm{T} / \mathrm{n}$ & 12 & & \\
\hline Exhaust from Power turbine & $\mathrm{T} / \mathrm{n}$ & 18 & & \\
\hline Total & $\mathrm{T} / \mathrm{n}$ & 30 & & \\
\hline 6.4. Steam Generation (Boilers) & & Boiler1 & Boiler2 & Boiler3 \\
\hline Pressure & $\mathrm{Kg} / \mathrm{cm} 2$ & 20 & 20 & 20 \\
\hline Temperature. & ${ }^{\circ} \mathrm{C}$ & 310 & 310 & 310 \\
\hline Installed capacity & $\mathrm{T} / \mathrm{h}$ & 15 & 15 & 15 \\
\hline Current Capacity & $\mathrm{T} / \mathrm{h}$ & 12.37 & 12.37 & 12.37 \\
\hline Steam/Bagasse Ratio & & 2.03 & 1.99 & 1.98 \\
\hline 6.5. Steam Consumption & & $\mathrm{T} / \mathrm{h}$ & $\%$ cane & \\
\hline \multicolumn{3}{|l|}{ Inlet steam to mill Turbine } & & \\
\hline Inlet steam to power Turbine & & $\begin{array}{l}12 \\
18\end{array}$ & $\begin{array}{l}15.0 \\
23.4\end{array}$ & \\
\hline Live steam make up & & $\begin{array}{l}10 \\
4.22\end{array}$ & 5.5 & \\
\hline Sugar Drying, sulfur, remelt & & 1.5 & 2.0 & \\
\hline Losses & & 1.4 & 1.8 & \\
\hline D. heating water & & 00 & 00 & \\
\hline Total steam Demand & & 37.12 & 00 & \\
\hline Exhaust balance & & $\mathrm{T} / \mathrm{h}$ & \multicolumn{2}{|l|}{$\%$ cane } \\
\hline Exhaust produced & & 37.22 & \multicolumn{2}{|l|}{48.2} \\
\hline Exhaust Required & & 30 & \multirow{2}{*}{\multicolumn{2}{|c|}{$\begin{array}{l}39 \\
6.65\end{array}$}} \\
\hline Surplus /deficit & & 5.22 & & \\
\hline Summary of Bagasse Balance & & Boier1 & Boiler2 & Boiler3 \\
\hline Steam GenerationRequired & & & 12.37 & 12.37 \\
\hline Steam/Bagasse Ratio & & 12.37 & 1.99 & 1.98 \\
\hline Bagasse Requirements & & 2.03 & 6.22 & 6.25 \\
\hline Bagasse Available & & 6.09 & 18.48 & \\
\hline Net Surplus Bagasse (Negative) & & & -0.08 & \\
\hline
\end{tabular}

The bagasse produced from the major commercial sugar cane varieties have on average $50 \%$ moisture, $14.5 \%$ fiber on cane. For a bagasse with moisture content of $50 \%$ the accepted standard fiber content in cane ranges from 12 to $16 \%$. The experimental result indicates the fiber content in cane of major commercial sugar cane varieties ranges from 13.67 to $14.78 \%$. The test result also indicates the quantity of bagasse obtainable from a unit weight of cane ranges from 29 to $33 \% \mathrm{wt} / \mathrm{wt}$ of cane. This gives on average $31 \%$ weight of bagasse per weight of cane. The standard value is 24 to $30 \% \mathrm{wt} / \mathrm{wt}$ of cane or approximately a quarter. The fiber content $\%$ in cane and the quantity of bagasse pro- duced by the factory is much better to supply the required quantity of bagasse for the boilers both during milling time and stoppage of mill.

\subsubsection{Heating or Calorific Value of Bagasse}

The results of experiment done on the higher heating value of bagasse at moisture content of $50 \%$ indicate the higher heating value ranging from 8396 to $8894 \mathrm{KJ} / \mathrm{kg}$ which is within the standard range. The calorific value of bagasse has also been determined for varying the moisture contents of bagasse. The purpose is to quantify the impact of the moisture content of bagasse on the amount of heat 
transferred to steam from bagasse during combustion in the boiler furnaces. The experience so far in the factory reveals moisture content has a significance influence on the performance of a boiler. This effect would be manifested when the moisture content of bagasse increase above $50 \%$; the boiler needs more bagasse or the boiler losses its pressure stability. The test is, therefore, intended to evaluate the boiler performance under a much wider spectrum of bagasse moisture. The test has been conducted on bagasse moisture content of $30 \%, 35 \%$ and $50 \%$.

The result shows the increase in the calorific value of bagasse with the reduction in its moisture content. It indicates it has necessary to dry bagasse to reduce the moisture content so as to improve its calorific value. This would improve the boiler efficiency. Moreover, the efficiency can be improved further by recovering the sensible heat that has been lost with the flue gas by employing it as the heat source in bagasse drying operation.

\subsubsection{Flue Gases Analysis}

The flue gas analysis indicates the carbon monoxide compositions of the flue gases on three boilers are 890 , 1230 and $1840 \mathrm{ppm}$, respectively when compared to the maximum allowable $480 \mathrm{ppm}$. The test also indicates the percentage of excess air in the combustions chamber, i.e., $79 \%, 89.7 \%$ and $98.7 \%$ and the composition of carbon dioxide in the flue gas is $10.9,9.8$ and 9.1 percent, respectively. However, the percentage of excess air to support complete combustion should lie in the range of $30-50 \%$. The analysis can be due to the addition of too excess air into the combustion chamber. This too excess air cools the chamber which in turn needs more energy to heat the air before combustion is started. The excess air due to its high pressure and velocity takes some of the carbon monoxide with it in the flue gases before it is completely converted into carbon dioxide. Moreover, the excess air that leaves with the flue gases takes more sensible heat with it than the conventional losses to the atmosphere. It is, therefore, very essential to optimize the percentage of excess air in the combustion chamber. This can be done by setting the percentage of carbon dioxide that leaves the combustion chamber to $15 \%$, which is the optimum percentage to support complete combustion in the boiler furnace, Hugot ET. Al. (1993). The maximum percentage of CO2 in the flue gases that can be theoretically achieved is $19.8 \%$ Hugot ET. Al. (1993). If it is needed to obtain complete combustion, without appreciable formation of carbon monoxide, it is desirable to work with the minimum amount of excess air, which will yield the optimum carbon dioxide percentage in the flue gases. By carrying out the optimization work on boiler furnaces, the optimum percentage of excess air in the combustion chamber is $32 \%$ as a result the optimum percentage of oxygen in the flue gases is $5.1 \%$.

The heat losses in the flue gases are determined using the ratio of the optimum excess air to the theoretically required air to support complete combustion. The optimum ratio is 1.32. The heat losses with the flue gases from each boiler are, therefore, $273 \mathrm{kcal} / \mathrm{kg}(1150 \mathrm{Kj} / \mathrm{kg}), 278 \mathrm{kcal} / \mathrm{kg}(1164$ $\mathrm{KJ} / \mathrm{kg})$ and $285 \mathrm{kcal} / \mathrm{kg}(1193 \mathrm{Kj} / \mathrm{kg})$ respectively. The percentage of heat recovered by optimizing the quantity of excess air in the combustion chamber for each of the three boilers are $18 \%, 27.4 \%$ and $29.1 \%$ respectively. After optimization of the excess air in the combustion chamber, the quantities of heat transferred into the three boilers are 1289 $\mathrm{kcal} / \mathrm{kg}(5395 \mathrm{~kJ} / \mathrm{kg}), 1285 \mathrm{kcal} / \mathrm{kg}(5384 \mathrm{~kJ} / \mathrm{kg})$ and $12798 \mathrm{kcal} / \mathrm{kg}(5359 \mathrm{~kJ} / \mathrm{kg})$, respectively.

\subsubsection{Proposed Possible Solutions}

To overcome the existing surplus bagasse problems of the factory and thereby to avoid the usage of wood as a boiler fuel during stoppage of mill, the combined improving actions were proposed as:

- Optimization of excess air supply in the combustion chambers.

- $\quad$ Application of bagasse drying system

- Increasing the capacity of the evaporators.

- Efficient operations and maintenance of boilers

- Optimization of Excess Air in the Combustion Chamber

By optimizing excess air in the combustion chamber the boiler efficiency increases 4-6\%. The gain in the above efficiency due to optimization of excess air will lead to save 1.56 tons of bagasse per hour after generation of the same quantity of steam as before.

\subsubsection{Bagasse Drying Application}

The experimental test results and the operational data have clearly indicated that the energy potential of bagasse has been under utilized. The result of the experiment shows currently, the drying of bagasse has taken much attention, as it is a power full tool to save bagasse energy in sugar industry. In the bagasse draying, the gases, which is the gaseous products of combustion leaving the combustion chamber is employed as a heat source to remove the water from bagasse. In doing so large quantity of sensible heat that has been lost with the flue gases are recovered. By applying the bagasse drying system, the gain in system efficiency is calculated from the change of the stack gas and is found to be $10.4 \%$. The calculation for the system assumes that there are no losses in the dryer. These are estimated to be about $4 \%$ losses in the dryer and are made as a correction on the final efficiency. The actual gain in system efficiency would then be, therefore, $6.4 \%$ and this leads to the savings of 2.2 tons / hr bagasse after generating the same quantity of steam.

\subsubsection{Increasing the Capacity Evaporator}

Increasing the capacity of the evaporator and utilizing the surplus exhaust steam that has been lost through blow down leads to increasing the crushing capacity of the mill to 90 tons $/ \mathrm{hr}$. The increment in crushing capacity of the mill leads to the production of 3.57 tons of bagasse per hour. This increment in evaporations and crushing rate of the mill don't affect the quantity of live steam produced and consumed. 


\subsubsection{Efficient Operations and Maintenance of Boilers}

In sugar cane boilers proper operations and maintenance $(\mathrm{O} \& \mathrm{M})$ procedures must be followed to insure safe and efficient operations. It is often assumed that good O \& M provides no energy savings because it simply "what should be done." In Shoa sugar Factory due to lack of proper O \& $\mathrm{M}$ energy consumption can increase dramatically as much as 10 to 20 present. Boilers suffer frequently from failure of the various systems including the pressure parts such as tubes, super heaters, air heaters etc. Thus, by carrying out only proper operation and maintenance the factory saves 10 to $20 \%$ of its energy consumption. The maintenance includes keeping physical components in good working order and within design specifications. This includes cleaning heat transfer surfaces, controls tuning, and maintaining insulations. Before boiler tuning system diagnostics should be performed and any deficient equipment brought back to specifications.

- By optimizing the excess air in the combustion chamber, additional $1.56 \mathrm{tons} / \mathrm{hr}$ of bagasse would be obtained as a surplus bagasse.

- By employing bagasse dryer the factory will save 2.23 tons $/ \mathrm{hr}$ of bagasse.

- By increasing the capacity of the evaporators to utilize the existing 5.12 tons/hr of exhaust steam which leads to the increment in crushing capacity of the mill as a result of which surplus 3.57 tons $/ \mathrm{hr}$ of bagasse is produced.

\section{Conclusions}

Based on the forgoing out puts of the research, the following inferences are made. All the experimental results, investigation and the analysis made on the physical properties of bagasse reveals that, its heating (calorific) value is quite enough to produce the amount of steam required by the factory both during milling time and stoppage of mill without requirement of any additional fuel such as wood like the current situations in the factory. The flue gases analysis made on three boilers of the factory shows high heat losses with the flue gases due to incomplete combustion of bagasse and excess air in the combustion chamber consequently the reduction in the boiler efficiency in which additional fuel is supplied to produce the required quantity of steam. The balances conducted on daily basis reveals there is even a deficit of bagasse at normal operations. The hourly live steam demand of the factory is 37.12 tons. However, at normal operation condition on average additional 0.08 tons of bagasse is demanded to produce the quantity of live steam required. Based on the balance conducted 35.12 tons/ hr of exhaust steam is produced by mill turbines and power turbines, however the exhaust steam demand of the boiler house is on average 30 tons $/ \mathrm{hr}$. This illustrates 5.12 tons/hr of exhaust steam is left as waste energy. Since mill has the capacity to crush up to $90 \mathrm{TCH}$, however, the capacity of the boiler house do not go beyond $77 \mathrm{TCH}$. On the other hand, the review of the evaporator shows there is ways of improving its capacity. Increasing the capacity of the evaporator and there by utilizing the surplus exhaust steam that has been lost through blow down leads to increasing the crushing capacity of the mill. The increment in the crushing capacity of mill to $90 \mathrm{TCH}$ yields the production of 3.57 tons of bagasse per hour. This increment in evaporations and crushing rate of the mill don't demand additional live steam requirements.

To overcome the existing shortage of bagasse problems of the factory and thereby to avoid the usage of wood as a boiler fuel during stoppage of mill, the researcher believes and strongly recommends to materialize the proposed solutions as they will improve the fuel economy of the factory there by alleviate the mentioned problems.

\section{Acknowledgements}

Authors acknowledge to department of chemical engineering, KIOT Wollo University and Shoa Sugar Industry for providing facilities.

\section{References}

[1] Meade-Chen, Sugar cane Hand book, a manual for sugar cane manufacturer and their Chemists Tenth Edition, 1997.

[2] J.Maurice Peturau, By-Products of the cane sugar industry, an introduction to their industrial Utilization, third completely revised addition, Elsevier, Amsterdam-oxford Newyork-tokyo, 1989.

[3] E.Hugot, Hand Book of cane sugar engineering, third completely revised,edition,ELSEVIER, Amstar Dam-oxfordNew York-Tokyo, 1986.

[4] John Howard Payne, Cogeneration in the cane sugar industry, sugar series 12,Elsevier Amsterdam-oxford-New YorkTokyo, 1991

[5] RSTCA, Regional sugar cane Training center for Africa Training Manual, Mauritius, 2001.

[6] N.J.Themelis, P.A. Ulloa, Methane generation in landfills. Renewable Energy, 2007, 32 (7):1243-1257.

[7] Villanueva, H. Wenzel, Paper waste - recycling, incineration or land filling, A review of existing life cycle assessments. Waste Management, 2007, 27:29-46.

[8] R.P.Beeharry, Carbon balance of sugarcane bioenergy systems. Biomass and Bioenergy, 2001, 20 (5):361-370.

[9] W.Chaya, S.H.Gheewala, Life cycle assessment of MSW-toenergy schemes in Thailand. Journal of Cleaner Production, 2007, 15(15):1463-1468.

[10] Eriksson, M.C. Reich, B.Frostell, A.Bjorklund, G. Assefa, J.O. Sundqvist, J.Granath, A.Baky, L.Thyselius, Municipal solid waste management from a systems perspective. Journal of Cleaner Production, 2005, 13 (3):241-252.

[11] M.Hauschild, H. Wenzel, Environmental Assessment of Products: Scientific Background, vol. 2. Chapman and Hall, London, UK, 1998. 
[12] D.Janghathaikul, S.H. Gheewala, Environmental assessment of power generation from bagasse, 2005.

[13] Bhattacharyya, C.Subhes, Applied general equilibrium models for energy studies: a survey" Energy Economics, 1996, 18:145-164.
[14] Moreira, R.Jose, J. Goldemberg, The alcohol program" Energy Policy, 1999, 27:229-245.

[15] K.Deepchand, A Note on the Pyrolysis Behaviors of Sugar Cane Fibrous Products. Biological Wastes, 2007, 20:203208. 